\title{
IGLESIA PARROQUIAL Y MEDIO RURAL EN EL ANTIGUO RÉGIMEN. NUESTRA SEÑORA DE LA ASUNCIÓN DE PALMA DEL RÍO (CÓRDOBA)
}

\section{SOLEDAD GÓMEZ NAVARRO}

Madrid, Ediciones Polifemo, 2020, ISBN 978-84-16335-71-8, 534 págs.

Tenemos en nuestras manos una nueva obra de la profesora Soledad Gómez Navarro, en la actualidad catedrática de Historia Moderna de la Universidad de Córdoba, y que desde el principio de su carrera profesional se ha dedicado con rigor y con acierto al estudio de la vida religiosa en la época moderna, temática de la cual es toda una referencia en la actualidad. Fruto de esta labor ha sido una nutrida producción académica, culminando (esperamos que de momento) con la obra objeto de esta reseña y dedicada al estudio de la iglesia parroquial de Nuestra Señora de la Asunción situada en la población cordobesa de Palma del Río.

Aparentemente, en un mundo académico muy amigo en los tiempos que corren de las grandes interpretaciones, y de los estudios globalizadores, es una cuestión de poca entidad. Pero que nadie se engañe: no hay temas pequeños, hay investigaciones pequeñas, y ésta en modo alguno lo es. Y no lo es, primero, por el rigor, la profesionalidad y el buen oficio del que en todo momento hace gala su autora. Segundo, porque no se conforma con su objeto de análisis, sino que continuamente está acudiendo al establecimiento de los necesarios marcos comparativos. $\mathrm{Y}$ tercero, porque el propio tema de estudio es de particular importancia.

Esta importancia se debe a que la parroquia ha sido la gran abandonada en la historiografía española sobre la Iglesia del Antiguo Régimen. Las órdenes religiosas siempre han gozado, desde los mismos tiempos modernos, de una producción histórica específica, ligada en muchas ocasiones a la propia congregación, y que se ha beneficiado de las pretensiones de eternidad y de continuidad en el tiempo de estas instituciones. Los obispos son la cabeza de la jerarquía eclesiástica, vinculados más o menos directamente a la propia capital del mundo católico, y, qué duda cabe, su actuación (o su falta de ella) contribuye a dejar impronta en el marco territorial que gobiernan. $\mathrm{Y}$ los cabildos catedralicios han constituido siempre instituciones poderosas, vinculadas a un edificio concreto, con un marcado espíritu de cuerpo, y con unos mecanismos de hereditariedad (la vía tío-sobrino siempre fue la predilecta) que, por medio de coadjutorías y resignas funcionaron perfectamente durante mucho tiempo. 
La humilde parroquia, sin embargo, no goza de estos privilegios. La perjudica su vinculación al mundo rural, poco atractivo, olvidado, y aparentemente inmóvil. La perjudica el ser un destino escasamente apetecible, dado la cortedad de sus rentas, y el escaso atractivo de su ubicación, que brindaba escasas posibilidades, y no necesariamente en este orden, de cultivar el espíritu, promocionar carreras, o acumular rentas. Y la perjudica la (presunta) mediocridad académica e intelectual de muchos de sus servidores, ya que licenciados o doctores de las grandes universidades españolas preferirán optar por destinos más brillantes y reconocidos.

Pero no podemos entender la vida interna de la Iglesia española de los tiempos modernos sin comprender el papel de la parroquia. Frente a unos obispos, cabildos y conventos de ubicación mayoritariamente urbana, la parroquia era omnipresente en el mundo rural, y constituía una tupida red de araña que llegaba a todos los puntos de la geografía. Es muy significativo que cuando los ministros, con razón o sin ella, denominados ilustrados, pretendieron materializar sus tímidos proyectos de cambio en el siglo XVIII, se dieran cuenta de la necesidad de contar con el apoyo, la comprensión y la dedicación de los curas, porque ellos eran capaces de llegar donde el Estado aún era incapaz de hacerlo.

La parroquia era además un referente obligado de la vida cotidiana. En el mundo rural el bautizo tenía lugar en la parroquia, la boda en la parroquia, y los funerales en la parroquia. La parroquia era el lugar de asiento de cofradías y de sepulturas, la misa dominical lugar de encuentro y conversación, y el cura la figura, un tanto ambigua, en la que lo mismo se podía encontrar comprensión y empatía, como presentar un talante más amenazador por estar en sus manos el poder, que en aquella época se tomaba muy en serio, de declarar la temida excomunión.

No es, pues, un tema baladí, acometer el estudio de la institución parroquial en la España moderna, y el que la autora haya tenido la valentía de hacerlo nos congratula. La lectura de estas páginas nos brindará un completo panorama de la Iglesia parroquial de la Asunción, sita en la localidad cordobesa de Palma del Río, durante los tiempos modernos, abarcando su marco territorial, su organización administrativa, sus servidores, sus recursos económicos, y los servicios prestados a la comunidad. Todo ello lo hace la autora con rigor, pero el rigor académico no está reñido, ni jamás debe estarlo, con el entusiasmo que debe generar en todo autor el tema objeto de análisis. Leyendo estas páginas se aprecia continuamente cómo la profesora Gómez Navarro ha disfrutado dedicando una parte (seguro que importante) de su tiempo al esclarecimiento de todas estas cuestiones. Y en nuestro mundillo historiográfico, dominado, e incluso esclavizado en la actualidad, por la 
necesidad de publicar a toda costa, ya que con las publicaciones se consiguen subvenciones, se obtienen proyectos, y se promocionan carreras académicas, con demasiada frecuencia se olvida de la necesidad de disfrutar del estudio del pasado, tanto más necesario por cuanto, ya que nuestro oficio no proporciona lustre social, ni lucro económico, al menos que nos aporte goce intelectual.

Nunca hemos creído en el presunto papel redentor de los historiadores. Los historiadores estamos para estudiar el pasado, no para ofrecer lecciones a los hombres o a las mujeres del presente. Y nuestro análisis del pasado nos permite comprender cómo las sociedades se enfrentaron a determinados problemas, y cómo fueron capaces de resolverlos (o no), pero en ningún caso nos permite ofrecer soluciones mágicas a los problemas de la actualidad. La creación de la red parroquial fue el medio que empleó la Iglesia para enfrentarse al problema de cómo controlar el territorio, cobrar las rentas, y gestionar la asistencia espiritual, y, dependiendo de los tiempos, cada uno de estos objetivos era el prioritario. Sus servidores actuaron en algunos casos con celo, en otros con entusiasmo, en otros con la justa profesionalidad, y en otros con la más total y absoluta indiferencia por sus obligaciones, sin que nunca seamos capaces de establecer en qué proporción se dio cada una de estas situaciones. Y los fieles podían sentir cariño, vinculación, o desapego por una iglesia parroquial que siempre estaba ahí, desafiando al paso del tiempo, y con la vocación de eternidad que siempre ha caracterizado el funcionamiento cotidiano y la mecánica interna de la Iglesia.

Arturo Morgado García

Universidad de Cádiz 